\title{
International Business and Institutional Change
}

\section{Masao Nakamura*}

Sauder School of Business and Institute of Asian Research, University of British Columbia, Canada

One of the main differences between domestic and international business is that international business (IB) comes with various risks that domestic business (DB) does not share. Examples of IB risks include the exchange rate risk, country-specific culture risk and political risk. Yet another IB risk encompassing a broad spectrum of uncertainties is the risks associated with an institutional change in a foreign country where IB investments have been made. There has been little systematic academic research regarding this sort of risk, of even a case study nature.

As an example of the latter sort of risk, consider the new business environments in Iraq and Afghanistan. Both of these countries are experiencing the departure of U.S. and other Western military forces. Resulting uncertainties include the unknown degree of Western democracy and customs that may remain after the Western military forces leave. Yet these countries are of considerable IB interest to Western firms, despite the risk, because of potentially high economic growth. These business risks combine political, economic, cultural and other types of risks. These risks might be compared to those experienced by Western firms when the Germany ceased to be divided by the Berlin Wall, or when the Soviet Union collapsed. Even though many Western firms thought they knew those countries, few were able to predict the timing and speed of the fall of the Berlin Wall or the collapse of the Soviet empire.

Of course, institutional changes that affect IB can occur in Western countries as well. For example, Japan's corporate governance (CG) reforms, which began in the mid 1990s and were intended to transform that country's inward-looking, bank-based CG system into a more market-based, transparent U.S. style CG system, has resulted in a mixed bag of actual CG changes. By now most U.S.-style CG institutional arrangements are allowed. So, a Japanese corporation potentially can run their management on an entirely U.S. style CG system driven by shareholder value maximization.

In reality, however, few Japanese firms have fully embraced U.S. style CG. This outcome was enabled though not expected, because, in adopting the U.S. style CG legal settings and institutions, the Japanese government proceeded with selective adaptation. With this approach, the new reform CG laws allow Japanese firms to choose, in multiple respects, between the U.S. style and the traditional Japanese style CG style practices.

While new transparency and disclosure practices have been implemented and the degree of enforcement is surely tougher than before, there is still a distance in this regard between Japanese versus U.S. and other Western countries' enforcement practices. Many Japanese firms continue to observe the traditional stakeholder welfare maximization principle. Hence shareholders still often have been left feeling powerless (with this being particularly true for even very large individual and foreign shareholders). The Steel Partners and other investment funds from the U.S. thought the Japanese M\&A market had become like the U.S. market following Japan's CG reforms and pursued hostile takeovers of some Japanese firms, assuming the outcomes would be consistent with the shareholder value maximization. But this is not what happened in many cases. Hostile takeovers are still not welcome in Japan to a large extent. The consequences of CG change in Japan have proved to be unpredictable [1].

Another example of an institutional change of a significant scale for Western business firms is taking place in Europe. It is well understood by now that having a single currency like the euro for many countries with very different economies leads to problems, especially when those countries still retain and exercise their own economic policies without binding central coordination (e.g., EU's current problems with Greece and other member countries). Already much uncertainty has resulted and firms with IB interests in Europe are already suffering related losses.

We expect that our new open-access research outlet, the Journal of Business \& Financial Affairs, will be particularly suited for timely research findings for issues involving rapidly changing world circumstances, including the type of business risks arising from rapidly changing national institutional change circumstances.

\section{References}

1. Nakamura M (2011) Adoption and Policy Implications of Japan's New Corporate Governance Practices after the Reform. Asia Pac J Manag 28: 187-213.
*Corresponding author: Masao Nakamura, Professor, Sauder School of Business and Institute of Asian Research, University of British Columbia, Canada Tel: 604-822-8434; Fax: 604-822-8477; E-mail: masao.nakamura@sauder.ubc.ca

Received February 13, 2012; Accepted February 14, 2012; Published February 17,2012

Citation: Nakamura M (2012) International Business and Institutional Change. J Bus \& Fin Aff 1:e107. doi:10.4172/2167-0234.1000e107

Copyright: @ 2012 Nakamura M. This is an open-access article distributed unde the terms of the Creative Commons Attribution License, which permits unrestricted use, distribution, and reproduction in any medium, provided the original author and source are credited. 